Journal of Engineering and Applied Sciences 15 (6): 1262-1266, 2020

ISSN: 1816-949X

(C) Medwell Journals, 2020

\title{
Identification of Blood's Metallothionein Gen Sequences as a Biomarker of Heavy Metal Exposure on the Gas Station Employee
}

\author{
Nur Kusuma Dewi and Ari Yuniastuti \\ Jurusan Biologi, Fakultas Matematikadan Ilmu Pengetahuan Alam, \\ Universitas Negeri Semarang, Indonesia D6 Building Floor 1 Sekaran, \\ Gunungpati Semarang, 50229 Central Java, Indonesia
}

\begin{abstract}
Metallothioneins (MTs) is protein which binds metal, plentiful cysteine and low molecular weight. Metallothionein binds essential metals and has some cellular functions, there are: transportation, storage and detoxification of metal, essential metal metabolism, scavenger free radicals and immune responses. When lead $(\mathrm{Pb})$ and Cadmium $(\mathrm{Cd})$ were absorbed, it would be quickly bound by metallothionein and transported by blood to liver. Metallothionein was coded by MTs gen. The objective of this study is to identify the sequence of MTs gen in the gas station employee's blood as a biomarker of body vulnerability by $\mathrm{Pb}$ and $\mathrm{Cd}$ exposure. This was a cross sectional study was conducted for 8 months and the location was a number of gas stations in Semarang and the sample were the gas station employees, as many as 52 employees. About $5 \mathrm{~mL}$ blood taken from each sample would be analyzed for the concentration of $\mathrm{Pb}$ and $\mathrm{Cd}$ by using Flame Atomic Absorbance Spectrofotometry (FAAS) and its MTs gen was analyzed by using Polymerase Chain Reaction (PCR). The data were analyzed by using SPSS for Windows 13 . The result showed that $\mathrm{Pb}$ and $\mathrm{Cd}$ level in the blood of each gas station employee were $14,23 \pm 2,54 \mu \mathrm{g} \mathrm{dB}^{-1}$ and $3,22 \pm 5,24 \mu \mathrm{g} \mathrm{dB}{ }^{-1}$ whereas metallothioneingen sequences showed $96 \%$ MTs gen expression are similar to normal human gen sequence according to BLAST GenBank. The gen expression of MT does not always reflect the accumulation of lead and cadmium in the gas station employee's blood. It is possible that MT gen sequence has a limitation when it used for a biomarker to detect any heavy metals exposure in human body to determine the susceptibility of heavy metals exposure.
\end{abstract}

Key words: Biomarker, metallothioneins gene, lead, cadmium, susceptibility, metals exposure

\section{INTRODUCTION}

Since, the beginning of the development over the past decade, biotechnology is getting a lot attention and play a role in important sectors of human life. One is that has penetrated in medical sector including diagnostis, prevention and treatment of various diseases. Diagnostic techniques and early detection of infectious diseases and genetic diseases has been developed such as hepatitis B, diabetes mellitus and thalasemia.

The use of biomarker is needed for detect and monitor the presence of heavy metals in the human body. In addition, the use of biomarker is capable for providing a data of heavy metal intensity absorbed by the organism sample and the toxicity and also the disturbances caused in biological system at a certain levels. Using the study of biomarker, heavy metal pullution in human body can be controlled as a prevention of serious disease.

Metallothionein (MT) is the material that belongs to a class of compunds of protein or polypeptide. Metallothionein (MT) is polypiptide which has a lot of cystein ties encoded by the gen has low molecular weight and be used for metal binding peptides (Zatta, 2008).
Metallothionein expression indicates there is a certain metal exposure (Hanson, 2008). The existance of metallothionein has at least two main functions, there are cleaning free radical materials contained in the body and detoxified metal to achieve a homeostasis (Carpene et al., 2007).

Various kind of metal and heavy metal are capable of competing at the metal bounding in metallothionein. These circumstances provide an advantage in the distribution mechanism of various kind of metal for the body's biological system of organisms. In various studies, it is known that there is a competition among the heavy metals to bind to form metalllothionein. Therefore, this research has been conducted to determine whether MTs gene can be used as biomarker for early detection of the heavy metal exposure in humans that indicate his susceptibility to heavy metals exposure.

\section{MATERIALS AND METHODS}

This research used cross sectional design. This research was conducted for 10 months in Semarang city. The examination of sample's plasma in Biochemical

\footnotetext{
Corresponding Author: Nur Kusuma, Jurusan Biologi, Fakultas Matematikadan Ilmu Pengetahuan Alam, Universitas Negeri Semarang, Indonesia D6 Building Floor 1 Sekaran, Gunungpati Semarang, 50229 Central Java, Indonesia
} 
Laboratory, Biology of FMIPA Unnes and Molecular Biology Laboratory, Biology of FMIPA Unnes Semarang. The sample of this research was 52 people and the entire sample was gas station employees in Semarang city who fulfilled the criteria and they were willingly involved in this research and they had signed the informed consent. Sample collecting method used purposive non random sampling. Inclusion criteria were male or female from 15-55 years old, willingly involved to be a respondent until the research is finished. Exclusion criteria were: About person with diabetes mellitus, critical kidney failure or chronic kidney failure, heart failure/aritmiakordis, chronic/critical liver disease, lung tumor or other fierceness, degenerative disease, stop the therapy, digestive disease, pregnancy or lactation and hormonal contraception, HIV/AIDS.

Substances used in this research were blood samples of gas station employees, aquadest, Trizol, chloroform, isopropanol, DH2O, Tris acetic-EDTA, agarose, loading dye, Ladder 100 bp, HotStart Master Mix Kit, primer MT2A forward 5'-CGC CTG GAG CCG CAA GTG AC-3' and reverse: 5'-TGG GCA TCC CCA GCC TCT TA-3'. Kit was used to examine heavy metals $\mathrm{Pb}$ and Cd-contents. Whereas equipment which were used were conivol tube $15 \mathrm{~mL}$, Pasteur pipette, stirring glass, Ependrof tube $1.5 \mathrm{~mL}$, micropipette 10, 20, 100 and $1000 \mu \mathrm{L}$, yellow and blue tip, centrifuge speed $6000 \mathrm{rpm}$, MicroFuse speed $14.000 \mathrm{rpm}$, refrigerator, shaker, autoclave, sample storage box, hand glove, PCR, AAS, electrophoresis. The blood's samples were taken, then their DNAs were isolated, MTs genes were amplified by primer and analyzed their sequence genes. Sequence data of MT2A genes which was obtained from gas station employees was compared by data from GenBANK NCBI.

\section{RESULTS AND DISCUSSION}

The sampling was going on May, 2015 in SPBU West, East and South Semarang. The amount of SPBU employee's blood samples which were obtained during blood sampling in East Semarang were 15 people in West Semarang were 17 people and in South Semarang were 20 people. So that, the entire research sample was 52 SPBU employees (Fig. 1).

Isolationand purification DNA: The result of isolation and purification DNA and also electrophoresis and PCR was obtained the figures of DNA bands.

The figures of DNA bands form one of the employees. About 6 samples of gas station employees which were used to represent to be sequenced were sent to laboratory of PT. Genetika Science Indonesia Jl. Duri Raya No. 5D West Jakarta, 11510, Indonesia. Sequencing examination was done to find out deeper about the order of metallothioneingene in gas station employees. That sequence gene was compared based on gene which was confirmed by National Centre for Biotechnology Information (NCBI Bethesda, MS, USA).

Sequencing DNA is a process or technique of determining nucleotide base order on a molecule DNA. Sequencing DNA can be used to find out the identity or function of a gene or other DNA fragments by comparing sequence of sample and other sequence DNA which is found. Sequencing method can be used to identify a gene mutation and it can compare gene homolog between species. In 1977 sequencing method has been developed in America which was pioneered by Maxam and Gilbert and in 1974 in England by Sanger. There are two sequencing method they are Maxam and lk Gilbert and Sanger method (Anwar, 2008; Aravind and Prasad, 2005).

The result of sequencing was obtained in the form of electroforegram. In electroforegram there were some curves with four different colors. Blue color shows Cytosine base $(C)$, black color Guanine base $(\mathrm{G})$, green color Adenine (A) and red color Timin (T). Electroforegram reading based on the color of the curve which was shaped into the highest point. If there is one
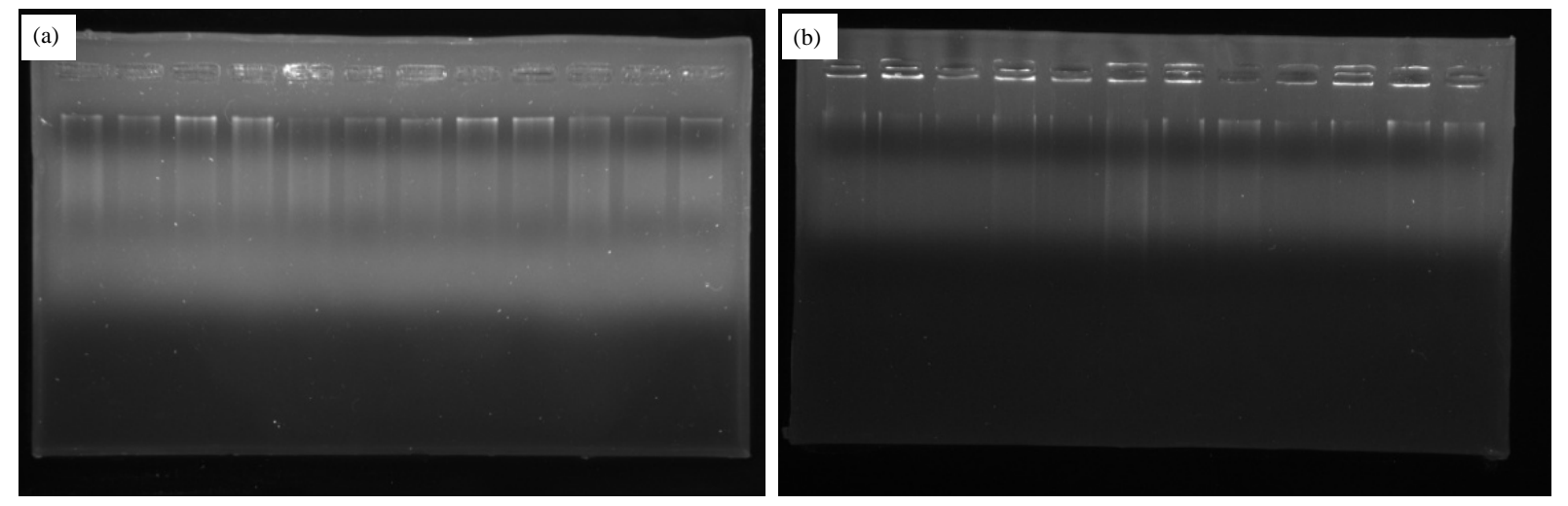

Fig. 1(a-b): (a) Result of isolation and purification DNA of blood sample of SPBU employee and (b) The result of sequencing gene MT-2A 
1

AAGCAGCATTCCCAAGTCCCGCTTTCACCCGCGCGCTAACGGCTCAGGTTCGAGTACAGG

ACAGGAGGGAGGGGAGCTGTGCACACGGCGGAGGCGCACGGCGTGGGCACCCAGCACCCG

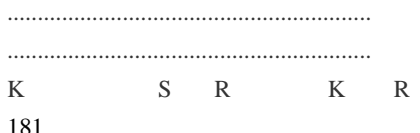

181

AGTGGGCCGCCTTCAGGGAACTGACCGCCCGCGGCCCGTGTGCAGAGCCGGGTGCGCCCG

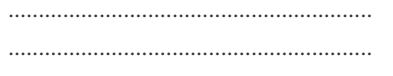

24

GCCCAGTGCGCGCGGCCGGGTGTTTCGCCTGGAGCCGCAAGTGACTCAGCGCGGGGCGTG

301

TGCAGGCAGCGCCCGGCCGGGGCGGGGCTTTTGCACTCGTCCCGGCTCTTTCTAGCTATA

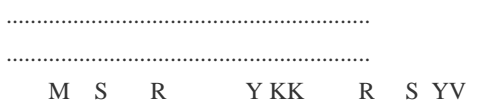

361

AACACTGCTTGCCGCGCTGCACTCCACCACGCCTCCTCCAAGTCCCAGCGAACCCGCGTG

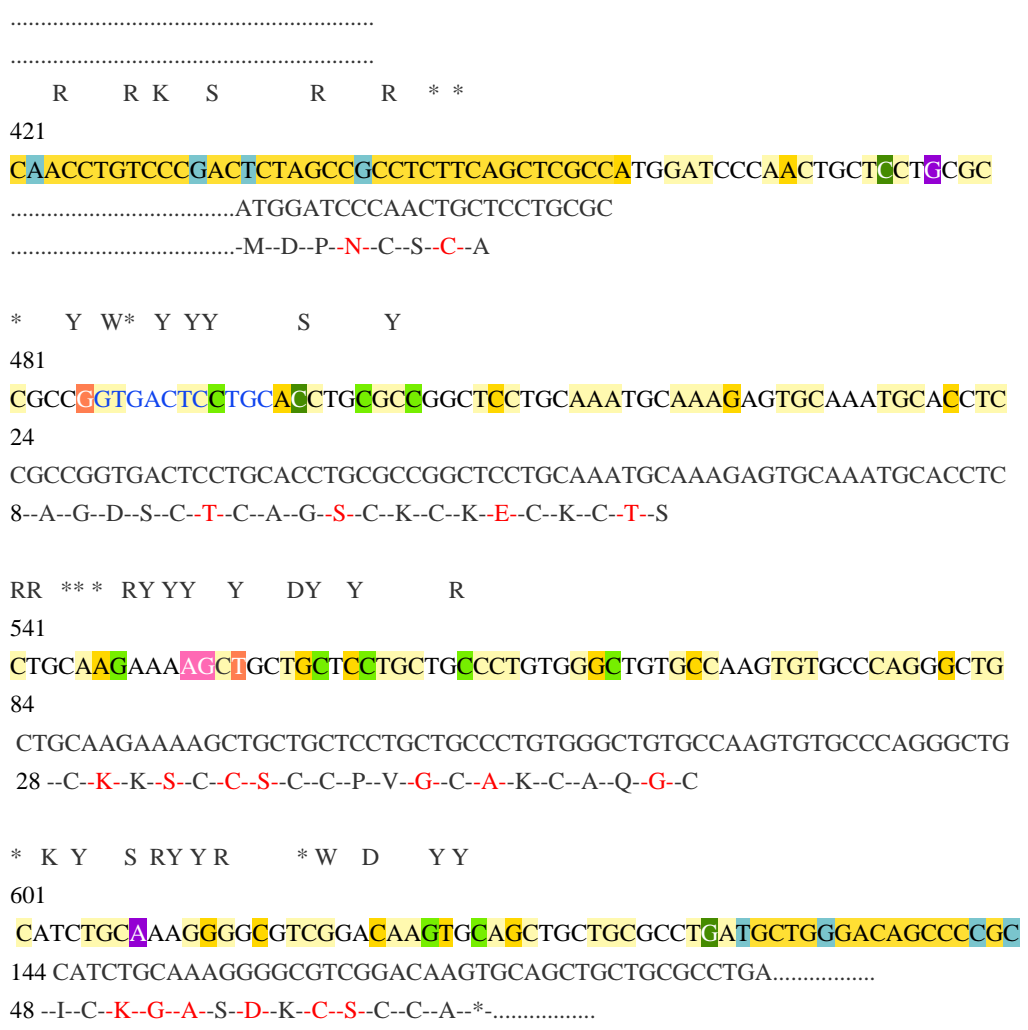




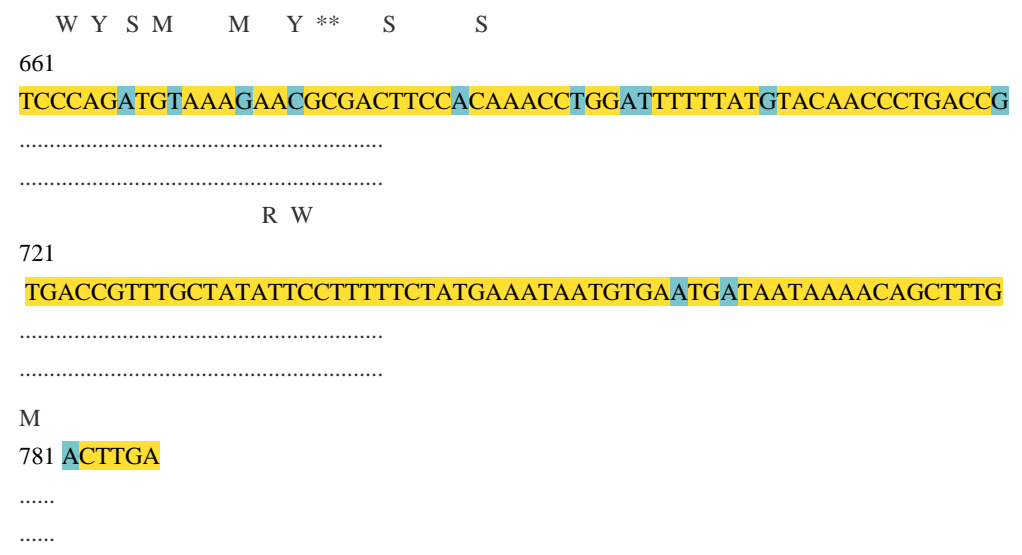

curve, then it is assumed that in that position there is homozygote allele pair. If there are two points of curve which have relative same point, then in that position they are assumed as heterozygote allele pair. The figure of sequencing DNA is presented in Fig. 1.

Based on the result of BLAST analysis it was found that there was variation of nucleotide in gene MT-2A which was examined with GenBankAcc No. GQ154088.1. The order of nucleotide base was in 388th and 608th order.

In this research the obstacle which was happened was in examining the annealing optimum temperature in order that primer could perfectly adhere, so that, DNA could be amplified. Therefore, optimize the temperature was done by trying some temperature ranges from $51-55^{\circ} \mathrm{C}$, until it was obtained that annealing optimum temperature was $53^{\circ} \mathrm{C}$. Besides that, the obstacle in this research was the composition of the best PCR reagent in order to make bands of amplified DNA result thick. In this amplified DNA it was found that the best DNA bands were with half of cocktail reagent. The good amplified DNA result was continued to the next level that was sequencing DNA by the help of genetica science institute's service in Jakarta.

The result was the nucleotide order in the form of ABI file it was edited by Bio Edit Version 7.0.9 program. Editing was done to vanish the base which was not needed by comparing sequence with chromatogram. The good result was obtained by alignment comparison in Clustal W. Sequence which was edited then it was placed in BLAST NCBI to find out the homology of sequence sample with the nearest species from GenBank's collections.

Based on the BLAST result from the sequence which was obtained shows that $96 \%$ on MT-2A gene with GenBank Acc No. GQ154088.1. The difference of nucleotide between MT-2A was figured through nucleotide sequence it was the result of BLAST alignment. So, it could be said that MT-2A gene was normal without exposed. The similarity was about $96 \%$ or close to $100 \%$. Thus, MT-2A gene could not be used as early biomarker detection to find out the susceptible toward heavy metal $\mathrm{Pb}$ and $\mathrm{Cd}$ exposed.

The amino acid alignment result shows that there was similarity of amino acid order MT-2A gene composer between samples and other samples in GenBank. The result shows that even in nucleotide level it could be seen that there was a mutation (transition or transversion) but the mutation was just silent mutation that was mutation on nucleotide which did not cause a change of amino acid, so that, it did not change the function from cytochrome oxidation I (Binz and Kagi, 1999). Codon with the pattern like this, according to Dale and Park was known as synonymous codons term. Zhang et al. added that other DNA characteristic was in the percentage of base contents (Carpene et al., 2007).

In human, MTs is coded by a group of genes which is located in chromosome 16q13 it is composed by ten isoforms MT functional. Protein is coded by four groups: MT1-4 protein. Human isoform MT has specific tissue expression pattern. The MTs expression increases in receiving several inducers such as metal interleukin, interferon and tumor necrosis factor alpha and glucocorticoid hormone.

\section{CONCLUSION}

In this cross-sectional study, it can be seen that MT gene of gas station employees $96 \%$ had similarity with sequence of GenBANK human gene, so that, expression of MT gene did not reflect lead accumulation and cadmium in gas station employee's blood. Therefore, sequence of MT gene is likely to have a base if it is used as biomarker to early detect the heavy metal exposed in human to find out a person's susceptibility toward heavy metal exposed. 


\section{REFERENCES}

Anwar, Y., 2008. Isolation and characterization of DNA fragment of type 2 metallothionein coding genes of Slamet cultivar soybean. MSc Thesis, Bogor Agricultural University, Bogor, Indonesia.

Aravind, P. and M.N.V. Prasad, 2005. Zinc mediated protection to the conformation of carbonic anhydrase in cadmium exposed Ceratophyllum demersum L. Plant Sci., 168: 245-254.

Binz, P.A. and J.H. Kagi, 1999. Metallothionein: Molecular Evolution and Classification. In: Metallothionein IV, Basel, B. (Ed.). Springer, Berlin, Germany, pp: 7-13.
Carpene, E., G. Andreani and G. Isani, 2007. Metallothionein functions and structural characteristics. J. Trace Elem. Med. Biol., 21: 35-39.

Hanson, N., 2008. Does fish health matter? The utility of biomarkers in fish for environmental assessment. Ph.D Thesis, Department of Plant and Environmental Sciences, University of Gothenburg, Gothenburg, Sweden.

Zatta, P., 2008. Metallothioneins in Biochemistry and Pathology. World Scientific, Singapore, ISBN-13:978-981-277-893-2, Pages: 317. 